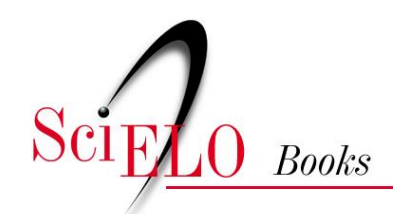

\title{
Relação entre textos
}

\author{
Geralda Medeiros Nóbrega
}

\section{SciELO Books / SciELO Livros / SciELO Libros}

NÓBREGA, GM. Relação entre textos. In: Hermilo Borba Filho: Memória de resistência e resistência da história [online]. Campina Grande: EDUEPB, 2015, pp. 117-163. ISBN 978-85-7879-334-0.

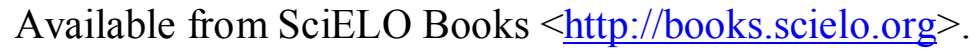

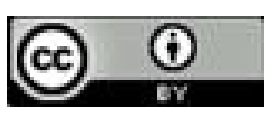

All the contents of this work, except where otherwise noted, is licensed under a Creative Commons Attribution $\underline{4.0 \text { International license. }}$

Todo o conteúdo deste trabalho, exceto quando houver ressalva, é publicado sob a licença Creative Commons Atribição 4.0.

Todo el contenido de esta obra, excepto donde se indique lo contrario, está bajo licencia de la licencia $\underline{\text { Creative }}$ Commons Reconocimento 4.0. 


\title{
RELAÇÃO ENTRE TEXTOS
}

\author{
"Afinal de contas, que é história da \\ literatura senão um legado de influ- \\ ências, uns influenciando os outrose \\ indicando caminhos?"
}

\section{Hermilo Borba Filho}

Gosto de me deter no discurso de Borba Filho e na gama variada de possibilidades que ele oferece ao estudioso de sua obra. Este escritor associa-se a grande número de escritores que trabalham como temática, categorias, inseridas numa cultura que ressalta o maravilhoso, o fantástico, respaldando o sexo e o erotismo, vigentes nas classes discriminadas. Sob este aspecto, é comum sentir que a escritura abre caminhos desconhecidos, quando o novo texto, relacionado com o texto anterior, passa a desenvolver significados compatíveis com o texto primeiro.

Lima (1993) resume os comentários por ocasião dos lançamentos das obras hermilianas e estranha que a crítica não se tenha detido em analisar como se dá a afinidade de Borba Filho com outros escritores ou como se realizam suas presenças, na obra hermiliana. A estudiosa assim se posiciona:

Deixou de ser ressaltada a característica mais marcante da obra deste pernambucano, através da qual, inclusive, se atualizam os demais trabalhos 
da literatura do romancista de Agá: o aproveitamento dos discursos preexistentes. Vale notar que, nesses discursos, se inclui o de Borba Filho ele mesmo, que migra de uma obra para outra [...] (LIMA, 1993, p.135, grifo do autor).

O texto deste autor se caracteriza quase sempre pela retomada do discurso anterior, o que representa uma questão de estilo que se organiza, nos contos, em torno de uma perspectiva cuja compreensão reflete a concepção do universo popular, parte inesgotável da motivação. Isto permite a Borba Filho desenvolver tendências literárias e técnicas discursivas, condizentes com o mundo objetivo que se propõe representar.

Enfatiza e atualiza discursos esparsos que em novos contextos estão submetidos à ideologia do cotidiano, adquirindo novos níveis de significação. Acatar que a elaboração estilística é de natureza sociológica é também poder deduzir que onde melhor se patenteia esta socialização do discurso será nesta interação de discursos que se atualizam e nesta influência do discurso anterior sobre o discurso atualizado. Assim, o novo discurso "responde a alguma coisa, refuta, confirma, antecipa as respostas e objeções potenciais, procura apoio, etc" (BAKHTIN, 1992, p.123).

Sob este enfoque, cito Lima (1993), que diz que o título do segundo volume da tetralogia A porteira do mundo se encaixa num trecho em que a personagem tem um temperamento irascível e o comentário da metáfora "a porteira do mundo" vale pelo interesse da pesquisa e pela pertinência da informação. São versos de teor popular e que são retomados pelo autor: "Mais pra baixo, meus amigos, tem um buraco profundo, pra quele que vem nascendo é a porteira do mundo", conforme pode ser observado: "Furiel, [...], que nasceu de dez meses só por teimosia e rasgara a mãe dum buraco a outro dizem que de dentada da raiva de estar transpondo a porteira do mundo (SDC, p.7). 
$\mathrm{Na}$ apreensão do discurso anterior, de princípio, me deterei em Bakhtin (1992, p. 132 e pas.), o que não impede a retomada do assunto, com a utilização de outros enfoques teóricos. Compreender a enunciação de um discurso anterior significa "encontrar o seu lugar adequado no contexto correspondente". O novo discurso pode adquirir uma nova significação que contradiz a sua significação anterior, daí a sua ambivalência como marca constante no discurso atualizado. O texto hermiliano, quase sempre repleto de interstícios preenchidos pelo discurso de outrem, conserva a sua integridade, sem alteração do contexto integralizador do discurso citado, como acontece em "Olho na rua e ouvido na cozinha" (AMS, p.83-87). A persona, poeta popular recuperando-se de uma doença, sente necessidade de escrever um folheto e busca inspiração, observando de uma janela o que acontece com o mundo lá fora. A história, no conto, vai-se desenvolvendo a partir do que é visto e ouvido pela personagem. O tom, predominantemente descritivo, introduz vez ou outra focos de diálogo, ocasião em que "o discurso citado e o contexto narrativo unem-se por relações dinâmicas, complexas e tensas". O texto fica assim arquitetado: descrição física de aspectos da natureza, narrativa de fatos observados (um homem assassina uma mulher), e intercalação do discurso anterior, representativo de jogos infantis. E assim constituem-se os elementos, necessários à escritura, quando a personagem/narrador "apanha o lápis de ponta afiada e começa a escrever o folheto" (p.87), colocando o narrador ponto final na escrita da história.

Num texto em que o tema é popular (feitura de um folheto) e em que o narrador questiona o seu trabalho: "Mas nada de histórias, de imaginação amorgada sem sair para ver o que acontecia pelo mundo" (AMS, p.83), nada mais natural do que aparecerem ingredientes do meio popular. Eis por que o discurso é popular, destacando "o contexto narrativo que o enquadra" (BAKHTIN, 1992, p.151). Por isso, concordo com Bakhtin quando diz que "o discurso literário transmite com muito mais sutileza que os outros todas as transformações na inteorientação (sic) sócio-verbal" (BAKHTIN, 1992. P.153), incluindo o 
discurso preexistente e o discurso atualizado, representativo da visão de mundo do autor em sintonia com o mundo objetivo, como se verifica no item seguinte:

\section{Convivência com o palimpsesto}

Voltando ao texto ora analisado, observa-se que o narrador, dispensando as aspas, dá a palavra à personagem, introduzindo um código próprio da literatura popular, pois a persona de "tão alegre que ficou cantarolando ai, ai, filho de coruja não tem pai" e em seguida "cantou a variante ai, ai, filho de puta não tem pai" (AMS, p.84). Este tipo de apreensão do discurso preexistente, na esteira de Bakhtin, representa "o discurso citado antecipado e o discriminado, no contexto narrativo e aparecendo realmente no discurso direto" (BAKHTIN, 1992, p.167) da personagem.

Não passa despercebida a construção da narrativa na tonalidade da personagem e o discurso da personagem na tonalidade do autor que, através do narrador instala a sua "visão de mundo". Surgem outras vozes (da mulher e da criança), vozes que se fundem, não se podendo mais distinguir do discurso indireto livre, pelas interferências do narrador e "no que concerne às apreciações e entoações, a retórica do autor e do herói [personagem] pode eventualmente sobrepor-se uma à outra" (BAKHTIN, 1992 p.172).

Quando quis continuar ouviu, lá dos fundos, da cozinha seria, a mulher com o menino: Foi um dia uma galinha pedrês, a pausa, o risinho da criança, deu um peido pra vocês três, não sabiam quais seriam, coisas do jogo seriam, e pinicainho da barra do vinte e cinco, risos aumentando, mingorra, mingorra, tire essa mão que já está forra (AMS, p.84). 
Neste mesmo texto, há passagens em que não se percebe a "convergência de dois discursos diferentemente orientados", noutras palavras é difícil perceber "a flexibilidade do discurso citado que resiste por trás da transmissão do autor” (BAKHTIN, 1992, p.173), situação em que se instala o discurso indireto livre:

\begin{abstract}
[...] então já estava bem perto da sua própria casa, estou com fome, coma um homem, os risinhos explodindo, o do menino meio nervoso meio contrariado, é pouco como um caboclo, é demais como um rapaz, aí era quase choro, é muito coma um defunto, o choro franco da disputa e a risada aberta da mulher, consolando-a, deveria estar embalando-a, o choro cessando (AMS, p.84).
\end{abstract}

Há, no conto em estudo, áreas da criação distribuindo a palavra de outrem e a palavra que parece ser a de outrem: "só sabia por ouvir dizer, que baixa não dava para a vista alcançar [...]” (AMS, p.85), quando o discurso preexistente é transmitido através do discurso indireto, o que não impede o retorno ao discurso indireto livre, quando o narrador, no final do texto, brinda o leitor com "a palavra com seu tema intacto, a palavra penetrada por uma apreciação social segura e categórica, a palavra que realmente significa e é responsável por aquilo que diz" (AMS, p.196): "A mulher e o filho haviam voltado para a cozinha e a voz dela recomeçava a brincadeira foi um dia uma galinha carijó, olhou para o papel, deu um peido pra você só" (AMS, p.87).

O discurso indireto livre estabelece um elo entre narrador e leitor até entender a artimanha do discurso que "permite a combinação das entoações da personagem e das entoações do narrador numa mesma e única construção linguística" (BAKHTIN, 1992, p.191). A fusão de vozes, a começar pela voz anônima do discurso primeiro, jungida à atuação da persona, agora no comando de todos os elementos necessários à produção do folheto, determina a situação em que as vozes são sintetizadas e comandadas pela voz do autor/narrador. 
Numa outra perspectiva, o texto hermiliano, visto como palimpsesto, pode incorrer um enfoque que Schneider chama de "teoria moderna". Para este teórico "textos primeiros inexistem tanto quanto as puras cópias, o apagar não é nunca tão apagado que não deixe vestígios, a invenção, nunca tão nova que não se apoie sobre o já escrito" (SCHNEIDER, 1990, p.71). Identificar o já escrito, no entanto, exige do leitor um repertório mais ou menos amplo que lhe permita senão identificar, mas pelo menos detectar o já-dito. Afinal, Riffaterre lembra que: "basta que o leitor reconheça uma citação: não é necessário que identifique seu autor" (RIFFATERRE, 1989, p.41). Ampliando a posição deste estudioso, nada mais natural do que acrescentar que o que ele diz aplica-se não só à citação, mas a qualquer nível de apresentação do texto preexistente, seja paródia, pastiche, estilização, paráfrase, plágio ou mesmo uma simples alusão, traço comum no texto machadiano e muito corriqueiro em Borba Filho. Reforço a posição de Riffaterre, situando Barthes:

O intertextual em que todo o texto é apanhado, visto que ele próprio é o entre-texto (sic) de um outro texto, não pode confundir-se com qualquer origem do texto: procurar as origens, as influências de uma obra é obedecer o mito da filiação; as citações de que um texto é feito são anônimas, identificáveis, e contudo já lidas: são citações sem aspas (BARTHES, 1984, p.54).

Como um autor como Borba Filho age conscientemente? Na descrição de uma cena de tortura de um de seus contos, uma personagem "já passava do amarelo para o verde pálido [...] parecia um calango vestido de fraque" (GEP, p.123). Compare-se com um sintagma de Almas mortas de Gogol (apud BAKHTIN, 2010a, p.433), em que a personagem "é um autêntico cachorro de fraque". Simples coincidência? O que não pode ser negado é que houve um diálogo entre os textos. Comparando, ainda, com Almas mortas, tradução de Tatiana Belinky, 
Abril Cultural, p.136: "orelhas empinadas e bigodes em riste" e também Almas mortas, tradução Costa Neves, Tecnoprint, [s.d]., p.101: “as orelhinhas tesas, inquietos os bigodes”. O que não pode ser negado é que houve um diálogo entre textos, para lembrar a teoria bakhtiniana. Ou será que se pode dizer que esta relação intertextual resulta do "actus purus da própria recordação" de que fala Benjamin (1985, p.37)?

Retorno a Barthes (1984), para dizer com ele que "a restituição do inter-texto (sic) anula, paradoxalmente, a herança”, e, aplico ainda o enfoque barthesiano, para dizer que sob determinados aspectos há textos hermilianos a que podem ser aplicadas as suas palavras: "o texto poderia muito bem tomar por divisa a frase do homem presa dos demônios (Marcos, 5, 9): O meu nome é legião pois somos vários" (BARTHES, 1990, p.58). E para corroborar o já exposto acrescento que "é bem isto o intertexto: a impossibilidade de viver fora do texto infinito" (BARTHES, 1993, p.49), não importando as fontes anteriores.

O conto "A anunciação" (GEP, p.117-127) ilustra a discussão acima, a partir do próprio título, que remete o leitor para o texto bíblico, do Evangelho de Lucas (1, 26-38). Um cartaz que se equilibrava no alto de uma casa comercial: "MINHA VIDA É VERBENA", é a causa de tudo. É preciso descobrir quem ousou colocar aquele cartaz e para isso há prisões, torturas e variadas arbitrariedades. O texto se desenvolve como um mosaico de citações esparsas em que a carnavalização caminha paralelamente para estabelecer a crítica a um sistema degradado. No destaque à arbitrariedade, o narrador parodia o sagrado. A personagem Otoniel, filho de Odin, foi crucificado no Cruzeiro, onde apareceu um cartaz com a legenda "O REI DOS FRESCOS”. Há, pois, um princípio de profanação.

Agambem (2007), discutindo a profanação, explicita que a profanação pode ter uma conotação política e tem a ver com o exercício do poder, o que é assegurado, remetendo-o a um modelo sagrado. Odin é um deus da mitologia escandinava. É interessante destacar "Rei dos frescos" e comparar com Rei dos judeus. Chamo ainda a atenção para "Otoniel, filho de Odin e Jesus, filho de Deus". "Por isso, se a ficção define a essência da literatura, a paródia se põe, por assim dizer, no 
limiar dela obstinadamente estendida entre realidade e ficção, entre a palavra e a coisa" (AGAMBEN, 2007, p.46). Também não descarto, neste contexto, a paródia como canto paralelo, o que converge para destacar a semiose da profanação.

Outros contos abrigam metáforas grosseiras com tendências à ironia, à crítica, à denúncia, assim como, ao humor e ao riso. Também o leitor se depara com clichês, como expressões estereotipadas, com predomínio de um tom popular. Toda esta representação está registrada em dicionários, o que permite familiaridade com estas variedades da linguagem. Valho-me de Riffaterre (1973, p.153) para aclarar o clichê, como estereótipo: "sua estrutura já o predestina a determinadas funções, seja qual for o contexto em que apareça".

Eis a gama de frases, expressões e fragmentos, presentes no conto: "eu termino tomando na jatoba"; "sovaco da região"; "precisava esgotar todos os recursos"; "levou um tapa olho"; "o pé da goela, se mal pergunto"; "procurando ar"; "calado estava, calado ficou"; "lá vai pergunta"; "chovia pergunta de todo lado"; "quase também que nem doeu"; "conversa vai, conversa vem"; "diabo de uma merda"; "esperar sentados"; "fela da puta"; "amor à primeira vista"; "fazer à vida"; "por livre e espontânea vontade"; "lançar um suspiro".

Contato, ainda, com a retomada do discurso bilaqueano: "para a dama nunca morrer assim, num dia assim", do poema "In extremis" (BILAC, 1978, p.107). É uma citação sem aspas que, no aparato da tortura, introduz um processo de deslocamento temático e semântico e no plano da representação destaca a cena ao mesmo tempo que promove o telos narrativo, fundindo semas contraditórios. Lê-se, pois, metalinguisticamente, uma citação com uma indicação explícita de sua paternidade: "lidei com as verbenas, da família das verbenáceas, conhecidas vulgarmente por camaradinhas, recitando pois o verbete do Dicionário da Língua Portuguesa de Jaime Seguier" (GEP, p.123). 0 narrador remete também para o imaginário infantil, o que acontece com a variação do título do conto dos irmãos Grimm, "João e Maria", o que pode ser detectado em "a mãe lhe contara todas as noites durante 
cinco anos, para dormir e lhe trazer pesadelos, a história da água meu netinho azeite senhora avó" (p.125), portanto "um caso de expansão de uma matriz" (RIFFATERRE, 1989, p.68), em que o diálogo entre a bruxa e João é utilizado como título da história, conforme está no texto ora estudado.

Neste conto, não há uma descrição por etapas, mas uma distribuição alternativa da qual os elementos dependem, ora do texto ora do hipotexto, que será posteriormente tratado, na esteira de Genette (1982), com função determinada, que se submeterá ao encaixe da sátira, como posso comprovar: "porque não sendo tempo de eleição nenhum babaquara os protegeria do castigo da justiça, que invocada seria e atingiria a todos, justiça não faz distinção de raça, religião e posição social [...]" (GEP, p.124).

A frase às vezes se desenvolve conforme a linha de menor resistência das associações estereotipadas, conferindo uma valorização humorística [trata-se da tentativa de impedir os desmandos do Cabo Luís, na prática arbitrária da tortura], como está no eufemismo: "cogitaram até de mandar o Cabo desta vida para a outra" (p.124).

Constato, através da leitura do texto hermiliano, que o discurso preexistente quer seja utilizado como discurso direto, indireto ou indireto livre, para usar o enfoque bakhtiniano, significa no discurso atualizado, apenas na dependência contextual, pois "a relação semântica está inteiramente dentro do texto" (BAKHTIN, 1992, p.27). É pertinente, também, usar do pensamento de Riffaterre que destaca a importância do leitor na modificação do texto. Crítico para quem "o fato literário é a dialética que funciona entre o texto e o leitor" (RIFFATERRE, 1989, p.103), aplicado ao texto hermiliano, vale ressaltar que "um leitor que partilha da cultura do autor, terá necessariamente um intertexto mais rico" (RIFFATERRE, 1989, p.77). O narrador hermiliano possui um estilo iterativo, pois sendo conhecedor do intertexto do meio popular, faz uso adequado do que está a seu dispor. Por isto, uma releitura de todos os pontos do texto, faz o leitor ter consciência do que o contexto literário está sempre motivado por referência não 
verbal, exterior ao texto. Não seria isto uma artimanha para com o leitor? Realmente, só se conhecem muitos dos textos hermilianos quando se leva em conta a apreensão do não-dito, não importam os artifícios utilizados para o desenvolvimento do processo através do qual "as representações, os fatos da mimese vêm a ser captados significando algo diferente do que aquilo que parecem querer dizer: essa semiotização define a literariedade do texto" (RIFFATERRE, 1989, p.103).

O código traz à tona a visão popular do mundo e formas utilizáveis do meio popular, no que se refere à linguagem e determina um complexo mimético da realidade o que, na ótica riffaterriana, é visto como o efeito do real. Também, grande número dos contos hermilianos se adequam a uma análise num enfoque apresentado por Ferrara (1986), uma vez que é comum deparar-se o leitor com uma gama variada de textos [texto aqui considerado até como fragmento de frase] num mesmo conto, fato relevante também em Ariano Suassuna. Para Ferrara (1986, p.103), "o problema da intertextualidade é de permitir a convivência de um ou mais textos no suporte de uma única estrutura textual sem que eles se destruam mutuamente, embora permaneçam centrados nas mesmas marcas ou indícios semânticos", o que pode ser elucidado com o texto "Cinco traques de velha" (GEP, p.105-116). Este conto, de arcabouço fantástico, focaliza os festejos populares do São João e a celebração do dia 31 de maio, festa de teor popular, em homenagem a Nossa Senhora, a mãe de Jesus. Para desenvolver a história, o narrador faz que muitos textos convivam entre si quando "a intertextualidade não só condiciona o uso do código como também está explicitamente presente em nível de conteúdo" (JENNY, 1979, p.6), acobertando trechos de discursos em que se nivelam várias áreas representativas de situações textuais diferenciadas, como estão em GEP:

a) Linguagem publicitária: “Almanaques do Pensamento, Bristol, Da Saúde da mulher" (p.105);

b) Referência a autores, como "La Rochefoucauld, Albino Forjaz Sampaio" (p.105-106); 
c) Explicitação da raiva: "o cu da puta que o pariu" (p.106);

d) Ditos populares, designativos da pornografia: "pinguelo da mãe caiu e o cachorro engoliu; macaco sobe e guariba desce, é, é o da mãe que padece" (p. 107);

e) Fragmento de frase, representativo do palavrão: "do cu da mãe" (p.107);

f) Discurso retomado de redação oficial: "vou fazer uma petição ao presidente da república solicitando que ao alto desta se digne promover decreto proibindo em todo território nacional a arte da piretologia" (p.107);

g) Fragmento próprio da linguagem oral: "se é homem apareça" (p.107);

h) Interjeição em nível de palavrão: “merda!" (p.107);

i) Linguagem de propaganda farmacêutica: "Saúde da mulher, Elixir de inhame, Biotônico Fontura, Papaverina” (p.109);

j) Discurso corretivo: "eu meto a peia" (p.110);

k) Discurso religioso, abrangendo o EU pecador, ladainha de Nossa Senhora, hinos religiosos, numa escrita bilíngue (latim e português popular), em que o que prevalece é a sonoridade das palavras: "[...] e o ofício começou com meas culpas, meas culpas oras pro nobis ad pecatoribus dominus tecuns a nossa fé ó Virgem regina partiu-a-carum queremos Deus que é nosso rei [...]" (p.110);

1) Clichês: "dito e feito; escarrado e cuspido" (p.112);

m) Alusão a personagens romanescas: "Fantasmas, d'Artagnan, Madame Bovary, Casanova, Judeu Errante, Pardaillau, Sherlock Holmes, doutor Watson, Ofélia" (p.113);

n) Gíria: "línguas estranjas" (p.114);

o) Provérbio: "boa romaria faz quem em sua casa está em paz" (p.115);

p) Linguagem jornalística: "matou baleias nas costas da Paraíba" (p.116). 
Neste texto, de fato, há a retomada de vários discursos, e o conto, que resultou num intertexto, "mediante a simples inversão dos fragmentos apropriados num novo texto (SCHNEIDER, 1990, p.132), ilustra a intertextualidade que, na teoria de Genette (1982), representa um dos modos da relação transtextual. A transtextualidade implica, necessariamente, o palimpsesto que funciona como corolário na "leitura de dois ou vários textos em função de um outro texto" (GENETTE, 1982, p.452), como no conto apresentado "Cinco traques de velha". O texto, pois, é palimpsesto, "incluindo e revestindo outros textos, incorporado junto com eles” (SCHNEIDER, 1990, p.378).

Bakhtin projetou o estudo do diálogo entre textos, seguido de Kristeva que trabalhou a intertextualidade. Outros estudiosos e cito alguns como Barthes, Jenny, Riffaterre, Schneider ocuparam-se desta vertente da teoria literária; dito isto, acrescento que, no próximo tópico, me voltarei para Genette, teórico que a partir do que havia sido feito, formulou a teoria da transtextualidade, distribuída em cinco relações transtextuais, respectivamente, intertextualidade, paratextualidade, metatextualidade, hipertextualidade e arquitextualidade.

\section{Trajetórias transtextuais}

A hipertextualidade se apresenta como toda relação que une um texto B (hipertexto) a um texto anterior A (hipotexto), como está em Genette (1982). Selecionei para análise o conto Romance de João-Besta e a Jia da Lagoa (AMS, p.88-96), com indicação explícita do hipertexto, uma vez que funciona como subtítulo (Sobre o folheto de Francisco Sales Areda). Quero demonstrar como Borba Filho utiliza o discurso preexistente e em seguida analisar o conto hermiliano sob um enfoque genettiano, o que confirma a hipótese de que o texto de Borba Filho se adapta a várias perspectivas de análise com o respaldo de teorias diversificadas, fato comum na literatura brasileira do Nordeste, a começar por Gregório de Matos, quando usa como hipotexto poemas de Gôngora e Quevedo. 
O folheto que se intitula 0 romance de João Besta e a Jia da lagoa, texto de literatura de folhetos, é constituído de setenta e nove estrofes, em forma de sextilhas e versos em redondilha maior, com esquema rimático xaxaxa. O tema é de encantamento. O poeta Sales Areda certamente retirou a história do conto "A princesa Jia" ou então usou a fonte oral, intitulada "A história de João Besta", história que as mães repassavam para os filhos, ainda crianças. O hipotexto do folheto já representa uma variante de "A princesa Jia" e se for levada em conta a história oral que originou o conto compilado por Câmara Cascudo, está-se diante de um processo de contaminação, tratado por Genette (1982). Cascudo (s.d., p.42-45) explicita, nos seus Contos tradicionais do Brasil, a provável origem do conto oral, acrescentando que em se tratando dos contos de encantamento, o gênero é universal, constando em todos os fabulários do mundo as princesas transformadas em macacas, rãs, serpentes etc, cuja quebra de encanto dependerá da coragem e da fidelidade dos namorados e servidores.

Relacionando o folheto de Areda e o texto hermiliano, sob a perspectiva do arquitexto (junção de gêneros diversificados), depara-se com o nível de atualização do discurso de Borba Filho, apreendendose o teor literário, numa outra marca discursiva. Examine-se um trecho de "A princesa Jia", para relacioná-lo com trechos do folheto e do conto de Borba Filho:

Assim que [João] colocou a Jia onde ela queria ficar, ouviu-se um estrondo e passou um clarão azul, tão forte que cegava. João fechou os olhos, deslumbrado, e quando os abriu, estava diante de uma princesa bonita como uma estrela, sentada numa carruagem dourada, com seis cavalos brancos e um mundo de gente vestida de seda, bordada de ouro e tremendo de brilhantes, esperando. Era um cortejo tão faiscante que João não podia acreditar que fosse verdadeiro (CASCUDO, s.d., p.44). 
Folheto de cordel

E então com meia légua, Como a Jia tinha dito, João foi abrindo a caixinha Deu um estrondo esquisito, Que ele caiu por terra, Dez minutos, quase frito!

Quando despertou estava, Nos braços de uma princesa. Olhou, não viu nem um sapo. Disse João: - Mas que beleza! Agora, sim, vou fazer A meu povo uma surpresa!

Todos os sapos que seguiram Em gente se transformaram Príncipes, reis, rainhas, músico Na carruagem rumaram Na casa do pai de João, Com dez minutos chegaram
Conto hermiliano

[...] e então com meia légua como a Jia tinha dito João abriu a tal caixinha deu um estrondo esquisito que ele caiu por terra dez minutos quase frito; e quando abriu os olhos estava nos braços de uma mui linda donzela e todos os sapos logo em gente se transformaram: governadores, deputados, senadores, músicos lá na entrada pararam. (AMS, p.95).

Se o hipertexto é todo texto derivado de um texto anterior por transformação indireta ou por imitação, vale dizer que a fronteira entre a imitação e a transformação é difícil de ser traçada (GENETTE, 1982). E, aqui, as amostras apresentadas ilustram o que está sendo estudado. Agora descarto o texto A princesa Jia, cuja fonte primeira é a oralidade e vou-me deter nas amostras de Areda e Borba Filho. Chamarei a atenção para a transformação e a imitação, quando o contexto exigir, quando destacarei outros dados da transtextualidade, como o processo de transtilização, reescritura estilística, uma transposição que se caracteriza como mudança de estilo (GENETTE, 1982). No texto hermiliano, a partir do título, a ausência do artigo generaliza o assunto, conferindo ao texto um caráter intensivo (LAPA, 1982). Já a composição do nome da persona, separada por hífen [João-Besta], 
no plano do estilo, destaca a característica predominante de "João", ou seja, o termo integra um composto popular, em que a motivação semiósica se sobrepõe à morfológica, adquirindo maior força expressiva (MARTINS, 1989).

Os elementos da cultura popular também estão ligados ao tema, como um assunto, à linguagem, ao estilo, à estrutura gramatical e/ ou outros. Neste hipertexto, há um processo de desvio em relação ao hipotexto, pelo acréscimo de outros discursos anteriores, retirados da oralidade, dos espetáculos populares ou de provérbios ou máximas, o que é constante no discurso de Borba Filho. O folheto inicia-se através da metalinguagem, usual na poesia de folhetos, cujo processo provoca em Borba Filho uma transformação por substituição, conforme a teoria de Genette (1982):

Vãobora rapaziada que é de noite o sol é quente, e amanhã vai chover, gritava um, saíam dois [...] (AMS, p.88).
O poeta é um repórter

Das ocultas tradições, Revelador dos segredos Guiado por Gênios bons, Pintor dos dramas poéticos Em todas composições (est. 1).

O narrador hermiliano desvia-se do hipotexto, pois começa por chamar a atenção para a personagem e, ao mesmo tempo em que suprime dados do folheto, adiciona novos elementos, o que Genette (1982) classifica como supressão e adição. No hipotexto, introduz-se a personagem, no hipertexto, a história que vai ser contada determina o retardamento da narrativa, pois o narrador introduz novos elementos no conto, priorizando a descrição, o que se enquadra na duração e frequência (GENETTE, 1982), destacando-se a plasticidade da linguagem em nível auditivo, cinético e visual. O narrador trabalha a linguagem no plano sonoro, gerando a harmonia imitativa, e o faz através de homeoteleutos. Observo, ainda, a ênfase dada à relação 
espacial, o que permite ao leitor perguntar: o que disse o narrador que não está aqui? Para em seguida acrescentar que João era um preguiçoso de alma sensível:

João-Besta ficava na rede se balançando, a rede no alpendre, olhando as nuvens, assobiando baixinho coisas que lhe acudiam à cabeça e que não tinha ouvido em canto nenhum, da minha lavra era seu orgulho dizer quando do assobio como tal qual flauta saíam os sonhos e as melodias, nos arredondados e trinados (AMS, 1982, p.88).
Por isso, chamo a atenção A toda e qualquer pessoa Para assistir a esse drama De uma história rica e boa, Sobre a vida de João Besta E a Jia da lagoa (est. 2).

As duas histórias se entrecruzam, quando da apresentação das personagens, o que na teoria genettiana resulta em contaminação. Num outro aspecto, o texto hermiliano gera intimidade com o leitor implícito: "saibam, que só se vendo", acobertando o texto de um novo estilo. As reiterações enfatizam a característica principal de João, que é o predomínio da sensibilidade, característica não aceita numa sociedade capitalista, em que o que tem valor são os bens materiais. É o mundo objetivo que me leva a esta dedução e acrescento que o universo estético é afetado pelo mundo exterior. Afinal, falar de uma coisa com insistência é chamar a atenção para o seu contrário. Para isto, o narrador expande o discurso, transformando os irmãos de João em seres abjetos, o que traz à tona todo um imaginário representativo do plano do real: 
Dois os irmãos, sabiam, eram Manuel e José, lordes, em bons cavalos esquipadores [...]. Manuel tacanho que só vendo querendo tudo para si e desgraça para os outros. José interesseiro que não podia ver vantagem que não enfiasse a faca pouco se importando no prejuízo alheio, zombadores de João, o besta, o besta da rede, das noites de lua, do assobio, o besta das flores e dos remansos [...] (AMS, p.88).
José e Manuel andavam Tudo lorde e bem tratado (est. 5)

Manuel era um tacanho, José muito interesseiro, E João, um tolo pateta, Muito humilde, hospitaleiro, Que não conhecia ganância, Nem gostava de dinheiro (est. 4).

No texto hermiliano, tempo e espaço estão implícitos; o tempo seria indeterminado, correspondendo, quem sabe, ao apogeu das zonas dos engenhos açucareiros do Nordeste, o que dá a pista para o espaço, determinado por "vaquejada", festa popular nordestina. o hipotexto situa o espaço na Grécia e o tempo é representativo da tradição oral. Há, pois, no conto hermiliano, uma translação espacial e temporal:

\begin{tabular}{|l|l|}
\hline $\begin{array}{l}\text { [...] no engenho do pai o Co- } \\
\text { ronel Cleto dos Santos Cunha } \\
\begin{array}{l}\text { Feitosa [...] os dois nas vaqueja- } \\
\text { das (AMS, 1982, p.88-89). }\end{array}\end{array}$ & $\begin{array}{l}\text { Lá num subúrbio da Grécia } \\
\text { Em tempos que longe vão, } \\
\text { Habitou um rico velho } \\
\text { Chamado Plínio Gastão (est. 3). }\end{array}$ \\
\hline
\end{tabular}

Aproveito para focar a personagem, pai dos três rapazes. É comum encontrar no texto hermiliano figuras de coronéis, com nomes destacáveis. O nome desta personagem introduz uma transformação. Outras variações temáticas estão subordinadas a um contexto cultural, variável no tempo e no espaço. Além de substituição, o desdobramento dos elementos textuais, subordinando o texto hermiliano a um processo de autohipertextualidade, associado que está a uma gênese textual, 
relacionada a uma nova realidade (GENETTE, 1982). A ampliação destaca a textualidade, conseguindo o narrador, através dos aspectos descritivos, instalar um aspecto sinestésico, que destaca o efeito poético, produzido pela sequência de imagens:

\begin{abstract}
[...] e lá se ia João nas tardes de crepúsculos vermelhos e tristes e nas manhãs de orvalho gitiranas arroxeadas, com modas esquisitas no assobio sem par, aqui e ali uma frase cantada na brisa, nos cabelos da montanha, ninguém entendia mas gostava, era João, o besta do João (AMS, p.89).
\end{abstract}

Embora se possa dizer que, na literatura de folhetos, "há histórias maravilhosas situadas em países longínquos, onde os costumes são estranhamente nordestinos" (MEYER, 1980, p.93), não posso negar que há, no texto hermiliano, esta tentativa de respaldar a essência do hipotexto, através da modalidade imitativa, em que os elementos básicos do tema não são desvirtualizados:

[...] os dois irmãos, avoados, se chegaram ao pai, ao impávido Coronel Cleto dos Santos Cunha Feitosa, em dizeres de correr mundo, na estreiteza do engenho não caberiam, nas endoenças muito menos e a alegria sempre a mesma da cidade já não os satisfazia pelo que, pelo que licença pediam para conhecer o oco do mundo, só que lhes faltava dinheiro e sua parte na herança receberiam mesmo em vida [...] só se foi dar-lhes a bênção nem bem pedida (AMS, p.90).
Os dois irmãos de João Besta Combinaram um certo dia Pedirem dinheiro ao pai Sendo em grande quantia Para andarem pelo mundo Bem longe da moradia (est. 6).

E pediram logo ao pai Para andarem o mundo inteiro $O$ velho disse: - eu consinto, Porém respondam ligeiro Se querem minha bênção Levando pouco dinheiro (est. 9)

Ou querem minha riqueza Com a minha maldição! (est. 10). 
Os elementos da tradição, pelo tom popular inerente ao hipotexto, apesar da ausência de fidelidade total do hipertexto, ora reduzem e ora ampliam o discurso atualizado, o que justifica citar Schneider (1990, p.101), quando diz: "entre uma obra e o espelho de literatura que ela reflete [aqui a literatura de cordel] o escritor se oriente por conta própria". No folheto, os irmãos de João rejeitam a bênção do pai, preferindo o dinheiro. João escolhe ser abençoado. Como se sabe, a bênção dos pais, entre o povo, faz parte de uma tradição muito arraigada e o termo quase sempre é usado na forma popular "benção". Nesta sequência, o hipertexto passa por um processo de desvio, quando se instaura ora o discurso indireto, ora o indireto livre, ora o direto:

[...] só foi dar-lhe bênção nem bem pedida [...] os dois botarem matulão nas costas [...] sem dinheiro?, sem dinheiro, e como farás?, eu me arranjarei, o patriarca aí emburrou, preocupado afinal leva alguma coisa, só sua benção... (AMS, p.90).
Que eu tendo, riqueza mesmo Me importo lá com benção! (est. 10).

Disse João: eu quero ir liso, Levando sua bênção (est. 14).

A permutação lexical (GENETTE, 1982) dá-se sem nenhum motivo implícito de mudança, ficando patente o nível de transtilização. No texto hermiliano, a possibilidade de utilização de um novo discurso e o efeito da rima em "ão", que conota um tom de tristeza, em seguida substituído pela alegria, retomando o texto a semântica do hipotexto: 


\begin{tabular}{|l|l|}
\hline [...] foi então o ancião e já lhe es- & Pois então, Deus te abençoe \\
tendeu a mão, com a outra no seu & Disse o pai lhe abraçando. \\
bolso lhe botou um só dobrão, fi- & E lhe entregou três moedas \\
cou tão alegre o João, João-Besta & João-Besta saiu cantando. \\
saiu cantando oi-oi-oi que estou & - Olé, olé que estou rico! \\
rico adeus até não sei quando & Adeus! Até não sei quando! (est. \\
(AMS, p.90). & $15)$. \\
\hline
\end{tabular}

No folheto, os dois irmãos decidem "correr mundo" e João, logo em seguida, toma a mesma decisão. No conto de Borba Filho, a decisão de João acontece "bem não era decorrida uma semana". Há o diálogo entre os irmãos, quando se instalam no hipertexto ligeiras transformações, por isto se patenteia com maior nitidez a imitação, beirando o pastiche, visto aqui não como imitação de um estilo, na esteira de Genette (1982), mas como rompimento com o plágio (SCHNEIDER, 1990), quando se dá um deslocamento espacial, na escolha do caminho a seguir, uma vez que João é que segue em frente, o que na semântica do texto tem sentido positivo. O tempo projeta-se espacialmente, sendo a categoria espaciotemporal determinante dos acontecimentos: 
[...] com bem dois dias foi encontrar os dois irmãos embaixo duma frondosa árvore plantada bem no centro duma encruzilhada [...] e na frente os três caminhos havia. Manuel disse somos três e três caminhos a quadra é satisfatória cada um segue por um pra ver quem ganha a vitória e José aí foi e disse também por sua vez que dali a um ano no mesmo lugar se encontrariam, teremos que nos juntar daqui iremos ora casa a nossa história contar; e um para a esquerda e outro a direita, e João -Besta em frente [...] (AMS, p.90).
Disse José: - É aqui

Que começa nossa história Somos três e três caminhos A quadra é satisfatória! Cada um segue por um, Pra ver quem ganha a vitória! (est. 19).

Porém, faltando três dias Para um ano completar, Neste mesmo arvoredo, Teremos que nos juntar E daqui iremos para casa, Nossas histórias contar. (est. 20).

Disse Manuel: - está certo.

$\mathrm{Eu}$ sigo o caminho em frente! E José, pelo da esquerda, Tomou rumo diferente. João seguiu, pela direita, Caminhando paciente. (est. 21).

O folheto de Areda, a partir da estrofe vinte e quatro (dois últimos versos), detém-se na personagem central, correspondendo, no texto hermiliano, à quarta página do conto. 0 exemplo abaixo, no início do hipertexto, apresenta um retardamento por desvio motivado pelos dados descritivos. A temática, no entanto, permanece inalterada, apesar das transformações lexicais, que não chegam a influenciar a semântica do texto. Na parte final, há um processo de imitação direta, apropriação, pois, o que faz lembrar Schneider (1990, p.54): "só se plagia o que se ama". Observo a influência da tradição, motivada pela expressão "na rede se espichar", em substituição a "deitar-se". Também é destaque a presença das categorias de tempo e espaço, criando um clima sentimental, como marca identitária do temperamento da persona: 
[...] já escurecendo ele fez seu paradeiro e arriou para descansar na sombra de um juazeiro, foi só armar a rede, fazer o foguinho, na rede se espichar, João-Besta, debaixo das estrelas, assobio claro, límpido, no veranico de Maio esperando a carne assar, mas nisto saltou uma jia tamanho de um cururu disse a João guarde essa carne que aí tem comer pra tu e mergulhou na lagoa macia como um muçu (AMS, p.91).
Adiante, numa lagoa, Ele fez seu paradeiro E arriou, pra descansar, Na sombra de um juazeiro (est. 25).

Armou a rede e deitou-se, Depois de ter descansado, Levantou-se e fez um fogo E se pôs, acocorado, Assando um taco de carne, Para comer um bocado (est. 26).

Nisto saltou uma Jia, Do tamanho de um cururu, Disse a João: - Guarde essa carne Que aí tem comida pra tu! E mergulhou na lagoa, Macia como o muçu (est. 27).

Há, mais uma vez, o retorno à apropriação, embora a ausência de pontuação, como em Bandeira, assim como a rima na prosa permitam uma nova dicção, o que explicita a "criatividade" no hipertexto:

\begin{tabular}{|l|l|}
\hline $\begin{array}{l}\text { Que vida boa esta minha brin- } \\
\text { car, comer e beber e dormir } \\
\text { nesta redinha (AMS, p.91). }\end{array}$ & $\begin{array}{l}\text { Que vida boa esta minha } \\
\text { Brincar, comer e beber, } \\
\text { E dormir nesta redinha } \\
\text { (est. 30) }\end{array}$ \\
\hline
\end{tabular}

O narrador hermiliano não perde a oportunidade de introduzir na narrativa uma categoria lexical de comida, o que amplia o texto, funcionando como elemento espacial, em nível narrativo/discursivo, motivado pela enumeração paralelística. A insistência em "comida" é própria da visão popular, uma crítica implícita à fome que é comum 
na literatura de cordel, como em Viagem a São Saruê. Em Geografia da Fome, Josué de Castro chama a atenção para este fato. Logo, é o excesso de comida que chama a atenção para as carências atávicas de quem convive com a fome:

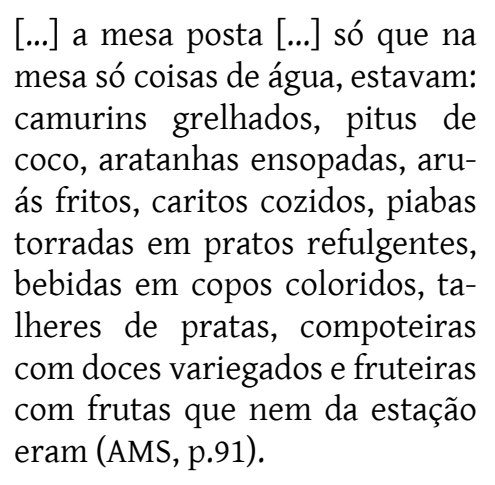
mesa só coisas de água, estavam: camurins grelhados, pitus de coco, aratanhas ensopadas, aruás fritos, caritos cozidos, piabas torradas em pratos refulgentes, bebidas em copos coloridos, talheres de pratas, compoteiras com doces variegados e fruteiras com frutas que nem da estação eram (AMS, p.91).

Sentou-se encostado à mesa Pra se servir do que havia: Bebida de toda espécie, Comer que ele nem conhecia Encheu a barriga e deu Graças a Deus e à Jia (est. 29).

Não quero desconstruir o que foi estabelecido, mas lembro que a semiose cultural estabelece a cristalização da cultura no texto hermiliano e explicita lugares de olhar e foco do folheto de Areda, o que na teoria genettiana corresponde à argumentação, com ligações explícitas com a metatextualidade, entendida como "relação transtextual que une um comentário ao texto que comenta" (GENETTE, s.d., 97). A partir deste eixo focal, o narrador faz uma citação direta, sem aspas, havendo apenas uma transformação lexical, pela substituição da interjeição "oh" por "ó", motivando a significância do discurso. A transformação sintática se dá pela ausência de pontuação, marca de inventividade discursiva, que atualiza e substitui a ênclise pela próclise, promovendo a transtilização. O narrador, no entanto, mantém a forma versificada. E para corroborar uma visão crítica, acrescento que o texto de Borba Filho se mantém refém da memória discursiva, no arquivo linguístico do folheto: 


\begin{tabular}{|c|c|}
\hline $\begin{array}{l}\text { [...] e quando se lembrou do can- } \\
\text { tador que vira e ouvira em feiras } \\
\text { dantanho [marca de atualidade], } \\
\text { cantador de nome Areda, foi só } \\
\text { dar como sua canção e cantá-la } \\
\text { em dó-de-peito: Ó luar do céu } \\
\text { luar / do luar sereno vejo / no } \\
\text { luar do luar luar / luar de lua te } \\
\text { almejo / neste luar enluarado / } \\
\text { meu luar me dá um beijo (AMS, } \\
\text { p.92). }\end{array}$ & $\begin{array}{l}\text { Oh, luar do céu, luar } \\
\text { Que do luar sereno vejo! } \\
\text { No luar do luar, luar, } \\
\text { Luar de Lua te almejo - } \\
\text { Neste luar enluarado, } \\
\text { Meu luar, dá-me um bei- } \\
\text { jo! (est. 38) }\end{array}$ \\
\hline
\end{tabular}

O hipertexto passa por processos de transformação que se apresentam como ampliação, redução ou substituição, o que se acumula numa mesma passagem do texto. Instala-se um andamento de prosa rimada e as reiterações e a própria paronomásia destacam os traços das transformações. O fragmento da frase "pegou na sua palavra" funciona como intensificação de um "modus" popular, ressaltando a ausência destes dados no hipotexto. A narrativa não se esgota e o narrador se reanima envolvido por uma memória prospectiva quando se "lembra" de investir num futuro que lhe propicie bem-estar e segurança: 
[...] te que um dia ele se decidiu, solteiro estava mas solteiro não ficaria, dono da lagoa seria, só que com a Jia casaria e isto mesmo lhe propôs e ela mais que depressa, de esverdeada para rósea ficando, pegou na sua palavra e tratou de fazer os preparativos que não lhe disse quais haveriam de ser, mas nela o moço confiava, confiança maior não poderia haver depois de tantas maravilhas tidas e havidas; [...] (AMS, p.93).
Até que João disse um dia Solteiro só vive à toa, Porém me acho feliz, Com esta Jia tão boa! Vou falar-lhe em casamento Pra ser dono da lagoa (est. 44).

E justamente propôs Casamento a Dona Jia. Ela com todo o prazer, Lhe respondeu que queria. Como noiva oficial Cresceu mais a alegria (est. 45).

Porém João ficou pensando Como era que casava Com aquela Jia feia, Mas que tanto lhe agradava Assim o tempo corria E o amor multiplicava (est. 46).

Detectado o amor de João pela Jia, resta à personagem cumprir o trato com os irmãos. Chegando em casa, cada um dos filhos conta de suas andanças. A voz plural, fruto do cruzamento de vozes tomadas de outro discurso, materializa-se no hipertexto:

\begin{tabular}{|l|l|}
\hline $\begin{array}{l}\text { [...] e era João, os olhos em cima } \\
\text { dele, sou todo ouvidos disse-lhe } \\
\text { o pai (AMS, p.93). }\end{array}$ & $\begin{array}{l}\text { Mas o velho olhou pra ele } \\
\text { E disse: João, vamos ver! } \\
\text { O que também arranjaste }\end{array}$ \\
$\begin{array}{l}\text { É necessário eu saber! } \\
\text { (est. 52). }\end{array}$ \\
\hline
\end{tabular}

João volta para a lagoa. O narrador não perde a oportunidade de introduzir um novo discurso, uma autocitação, que também está 
presente em Espetáculos populares do Nordeste, também presente no conto "O almirante", com ligeiras transformações: a persona canta "olé olé olé ô triques ô maria - olé que as ondas do mar lá fora não são como cá" (AMS, p.94).

Há uma transformação temática na relação da Jia com João; positivo no hipertexto e negativo, no folheto, pois o poeta ressalta o mal-estar de João em adaptar-se ao inusitado da situação, enquanto no texto de Borba Filho o narrador destaca o amor vivido naturalmente, o que se explicita na cena do casamento. Há um teor mais alusivo do que propriamente de retomada do texto anterior. Observa-se também a forma expressiva de "mal bem-casados estavam" que atualiza, no discurso hermiliano, traços de diferenciação entre os dois textos:

\begin{tabular}{|l|l|}
\hline [...] quanto mais se mandava mais & Na hora chegou a Jia, \\
seu coração cantava [...] a Jia toda & Toda trajada de branco, \\
vestida de branco, ali se juntaram & De palma, véu e capela, \\
os sapos, juntou-se a Jia com João, & Pisando com passo franco. \\
celebrou-se o casamento com & E João dizia consigo: \\
toda a ostentação; e mal bem-ca- & - Vou enfrentar o barranco! \\
sados estavam e João-Besta olhou & (est. 64). \\
de lado [...] (AMS, p.95). & \\
& João sentou-se com a Jia \\
& Muito triste e pesaroso, \\
& E oito sapos puxaram \\
& O cortejo valoroso (est. 68). \\
& \\
\hline
\end{tabular}

Como já foi apresentada a desmetamorfização da jia que se transformou em uma linda donzela, acrescento que, aplicando a teoria da transtextualidade, já uma transocialização, adaptável ao mundo objetivo, o que reforça a transformação ideológica, vista dialeticamente como adaptação ao contexto da narrativa hermiliana. A substituição de Oriente [alusivo, nos contos tradicionais, a um clima de magia e encantamento], por ocidente [que se associa ao mundo real, no 
contexto do discurso hermiliano] atualiza o conto do escritor pernambucano, num espaço/tempo identificados, daí donzela substituir "princesa". "Príncipes, reis, rainhas" correspondem, no texto hermiliano, a governadores, deputados, senadores. 0 final do hipertexto traz marcas de diferenciação em relação ao hipotexto. Mas, indo-se por etapas, destacam-se dados aproximados, quando há a focalização do pai dos três irmãos:

[...] foi ele quem mais gritou eita cortejo importante e João traz uma donzela a mais linda do ocidente (AMS, p.96).
O velho estava na porta, Soltou um grito estridente, Dizendo: - Lá vem João Besta Com um cortejo imponente E vem trazendo a princesa Mais linda do Oriente! (est. 58).

O desfecho em relação aos dois irmãos de João é funesto, nos dois textos, o que pode ser visto como a manutenção do mesmo traço semântico:

[...] mas os irmãos subitamente de preto e também pretos iam ficando enquanto a festança andava, saíram da mesa e no mato se escafederam, ficaram as esposas e em pouco mais no pipocar do champanha as ditas estavam em despautérios, o Coronel Cleto dos Santos Cunha Feitosa mandando que as fechassem a sete chaves no recesso da camarinha (AMS, p.96).
E recitaram sonetos -

Sem se lembrarem dos outros Que de ódio estavam pretos (est. 64).

Manuel, com esse desgosto, Tomou veneno e morreu. José também enforcou-se, Sua noiva enlouqueceu. A outra ganhou o mundo Nunca mais apareceu! (est. 65). 
A última estrofe do folheto vem em forma de acróstico e, como nos contos populares, e na Literatura de folhetos, conclui, mostrando que os maus são castigados e os bons, recompensados. Ao mesmo tempo destaca que a bênção dada pelos pais aos filhos tem muita credibilidade, na cultura popular. É o mito como "tradição sagrada, revelação primordial ou modelo exemplar evocativo de um tempo remoto da vida de um povo" (ELIADE, 1972, p.8).

O conto hermiliano afasta-se do folheto, como se o hipertexto perdesse o vínculo com o hipotexto, havendo uma transformação por substituição. O que vai, então, prevalecer no texto hermiliano? $\mathrm{O}$ autor/narrador enfatiza a cultura popular, cadinho de presença da tradição, compromisso do autor, introduzindo um discurso representativo do final de muitas histórias orais e contos populares, como em Cascudo (s.d., p.55):

\begin{tabular}{|l|l|}
\hline $\begin{array}{l}\text { [...] eu vinha com um prato de } \\
\text { doces quando foi na ladeira do } \\
\text { quiabo escorreguei e o prato } \\
\text { se foi [...] (AMS, p.96). }\end{array}$ & $\begin{array}{l}\text { Foram três dias de festas e } \\
\text { danças e até eu me meti no } \\
\text { meio, trazendo uma latinha } \\
\text { de doce mas na ladeira do } \\
\text { Encontrão, dei uma queda e } \\
\text { ela, pafo! no chão! (CASCUDO, } \\
\text { p. 96). }\end{array}$ \\
\hline
\end{tabular}

Por outro lado, o leitor de Borba Filho sabe o lugar de destaque que o sexo ocupa em sua literatura, criando não só um clima de sensualidade e erotismo, mas, também, representando o ludismo, através do jogo de palavras, numa linguagem sexualizada, que assume tão grande importância que se transforma num dos itens mais destacáveis de sua escritura. Mas mesmo que o narrador hermiliano represente o sexo, através de uma "linguagem proibida" (pornográfica e obscena), com predomínio de palavrões, este dado não chega a refletir o lugar comum, nem o meramente grosseiro, pois no plano literário ressalta 
uma perspectiva orgástica, advinda de uma linguagem que provoca sensações erótico-literárias. A linguagem, pois, destaca o nível estético, quando o poético e o erótico intercalam, fazendo sobressair o estilo. O autor consegue este resultado, no final do seu conto, adequando as palavras a ressonâncias líricas que refletem recursos literários, pertinentes ao verso e à prosa. 0 tema da sexualidade, instaurador do discurso, faz aflorar os efeitos esperados.

Observo, no hipertexto, o emprego do número sete em "Sete dias e sete noites" que determina a plenitude na vivência do amor. "O número sete é significativo em quase todas as culturas; na Bíblia, significa totalidade, plenitude, complementação" como está em Mackenzie (1983). Também nos contos de fadas e nas tradições populares o sete desempenha um papel importante como número da totalidade, como está em Lexicon (s.d.). O narrador, senhor de sua matéria, sabe a que se propõe e, colocando a linguagem à sua disposição, estabelece o grau de erotismo, na detectação do prazer como em "boca com boca". O verbo onomatopaico "assobiar" identifica o plano sonoro e, no fragmento da frase "sem poder assobiar", ratifica o forte envolvimento das personagens. A sequência dos adjetivos "inesgotável” e "perdurável" são elementos do mesmo campo semântico e enfatizam a semiose do número sete. "Amável" e "agradável" estão ligados ao campo associativo do prazer e a forma apocopada de muito ("mui"), atua como elemento de intensidade ao mesmo tempo que colabora na ritmicidade do enunciado. A culminância está no emprego do neologismo "lesco-te" em função da estrutura combinatória do conjunto dos elementos de linguagem que traduzem o ato sexual. Lembro que o neologismo, na estrutura de Riffaterre (1989, p.62) "é capaz de resumir todo um sistema descritivo, de condensá-lo em um signo", sendo neste contexto como a metáfora sonora do sexo. No final do conto, está implícito o modo peculiar de encerramento dos contos tradicionais: "casaram-se e foram felizes para sempre", o que tiraria do texto hermiliano grande parte de sua força expressiva, se o narrador tivesse 
trilhado um caminho explícito. Há, pois, no final do conto uma transformação por substituição nos moldes genettianos:

[...] João se trancou com a donzela e com ela, por mais sete dias e sete noites, boca com boca, sem poder assobiar, dando-se ao jogo inesgotável e perdurável, mui amável e agradável do lesco-te, lesco-te (AMS, p.96).
Filho sem bênção dos pais, Sempre é mal sucedido. Agora, João, por ser bom, Livrou-se e foi protegido E então por João da lagoa Seu nome ficou conhecido. (est. 78)

Não se esgota, nos contos do escritor pernambucano, o feixe de relações transtextuais. Entre outros contos, destaca-se "A trágica estória do Doutor Fausto e o cão do segundo livro" cujo hipotexto é Fausto, de Goethe. Dificilmente se encontra um texto de Borba Filho que não faça o leitor perscrutar na memória ecos da transtextualidade. Schneider (1990, p.132) lembra que apesar "de substituição, distanciamento, acréscimo [...] que contribuem pouco a pouco para apagar o texto primeiro sob uma série de variações cada vez mais distantes", reconheço que Borba Filho sabe captar a essência do texto original, submetendo-a a diferenças de grau e de natureza. As duas relações da prática hipertextual estão presentes no palimpsesto hermiliano, respectivamente a transformação e a imitação, em suas várias modalidades. Ressalto, ainda, que nos contos de Borba Filho os elementos descritivos funcionam como um fator de destaque e, mesmo atrasando a narrativa, a história diz o que o narrador se propõe. Kristeva (1980, p.143) afirma: "no espaço de um texto, vários enunciados, vindos de outros textos, cruzam-se e neutralizam-se". Esta técnica que é uma marca na escritura de Borba Filho é comum também na literatura brasileira do Nordeste e do Brasil, principalmente a partir de 1922. 
O texto hermiliano, através da amostra apresentada, explicita as diversas modalidades que Genette designou por transtextualidade. A transcendência textual, no escritor pernambucano, vai mais além se relacionada ao mundo objetivo que, apreendido ficcionalmente, focaliza não só o que é representativo do mundo popular, mas também registra as marcas de um tempo que se caracteriza pelo medo, pela perda da liberdade, pelo silêncio, pela negação de vida plena. O palimpsesto do texto de Borba Filho, numa primeira instância, é a própria História. Reconhece-se ser possível, muitas coisas serem verdadeiras, ao mesmo tempo e "assim a verdade passa a identificar-se com o que não é dito ou com o que é dito de forma obscura" (ECO, 1994, p.35). Para isto, o autor não se limita apenas a representar o discurso alheio, mas reutiliza o seu próprio discurso, o que se verá em seguida.

\section{Percurso interno do intertexto}

Já posso falar de uma autotranstextualidade que se apresenta a partir da trama da hipertextualidade em que Borba Filho busca o hipotexto do meio popular provocando uma relação consigo mesmo, que chamo de "intertextualidade interna", entendendo-se esta como uma "relação de um texto consigo mesmo", para usar uma terminologia de Dallenbach (1999, p.52). Uma "autotextualidade", termo que Sant'Anna (1985, p.62) utiliza como sinônimo de intratextualidade. Penso, então, no texto como a produção textual de Borba Filho, incluindo não só a ficção, como o teatro e a ensaística.

$O$ autotexto hermiliano resulta quase sempre da retomada de textos dos espetáculos populares, como o Bumba-meu-boi, Mamulengo, Pastoril, Fandango. O Padre que é uma personagem do Bumba-meu-boi:

[...] em alguns bumbas faz o casamento de Mateus e Catarina, mas no de Antônio Pereira vem especialmente para confessar $\mathbf{0}$ 
morto-carregando-o-vivo que é um ator mascarado, com o tronco de um boneco na frente e os membros inferiores atrás, dando a impressão perfeita de que o inanimado carrega o animado. (BORBA FILHO, 1966, p.27, grifos do autor).

Borba Filho critica o Padre Lopes Gama que, por não conhecer o sentido do popular, aplica a "carapuça" em tudo que para ele ia contra o decoro, não aceitando a brincadeira em torno de um sacerdote (BORBA FILHO, 1996, p.19). Estas liberdades, no contexto do próprio auto, consistem em versos declamados pelo padre de mentira, o que:

[...] é um exemplo agudo da dissociação personagem-intérprete e do sentido realista anti-realista comum a todas as formas de espetáculos populares, onde não se pretende impingir a mera representação do real, mas - naquele sentido estético de alguns teóricos da arte dramática - a teatralização do teatro (BORBA FILHO, 1996, p.19).

O padre do bumba de Antônio Pereira que vem para confessar o Morto-Carregando-o-Vivo, entra "cantando e dançando, quebrando toda a ilusão":

Quem me vê assim dançando

Não pense que fiquei louco

Não sou padre não sou nada

Virei secular há pouco (BORBA FILHO, 1977, p.28).

Os versos declamados pelo padre de mentira se apresentam em Espetáculos populares do Nordeste, com uma variante mínima, se forem levadas em conta a flexão do verbo e a ausência de pontuação: 
Quem me vir assim dançando

Não julgue que fiquei louco.

Não sou padre, não sou nada,

Virei secular há pouco (BORBA FILHO, 1976, p.19).

E como estes versos se apresentam no contexto da ficção hermiliana? Leve-se em conta que, variando o contexto, varia também a semântica do texto. Em Os ambulantes de Deus, o padre, entre outras personagens do Bumba-meu-boi, apresenta-se como ator em "empolgante espetáculo lítero-instrutivo onde se demonstra que a maldade humana nem sempre é recompensada mas que enquanto dura, dói” (BORBA FILHO, 1976, p.104). A personagem Manuel de Tal está amarrada num poste, torturada por subversão e quando lembra ao padre-capelão que ele é o sal da terra e a luz do mundo, tem como resposta os versos:

Quem me vir aqui dançando

Não julgue que fiquei louco

Não sou padre não sou nada

Virei secular agora há pouco (BORBA FILHO, 1976, p.115).

Em Sobrados e mocambos (1972), a personagem Padre Lopes Gama [uma sátira?] após confessar uma mulher, cujo pecado maior é exaltar o sexo, impinge-lhe três penitências e, furioso e num último arranco, cita os versos:

Quem me vê assim dançando

Não pense que fiquei louco

Não sou padre não sou nada

Virei secular há pouco (BORBA FILHO, 1972, p.52). 
O resgate deste trecho se consuma no conto O Padre (AMS, 1976, p.78-80), texto que se caracteriza pelo tom grosseiro que traz, à tona, aspectos pornográficos e obscenos da orgia sexual. o texto corresponde a uma representação do Bumba-meu-boi, sob aspecto diferente. A partir disto desenvolve-se uma relação orgástica envolvendo o padre, cinco beatas e um cachorro. E, assim, instaura-se o hipertexto , ao mesmo tempo que o autotexto caminha pelo espaço do conto, mostrando o autor através de sua perspicácia criativa, que é possível amoldar o mesmo discurso a contextos diferentes, situação em que a temática pode ser a mesma, embora se possa atribuir uma significação diferente, permeada por sentidos ambíguos ou ambivalentes. A estrofe, neste conto, dilui-se no texto, prosificando-se, o que não modifica o conteúdo do texto preexistente:
[...] e as beatas se agitavam agoniadas, vestiam-se, o Padre também, agarravam-se, dançavam num bolo só, para cada uma beata o Padre tinha uma ejaculação, assim no ar, então já ia nascendo o dia, o cachorro regalava-se, tudo lambia, todos lambia, era tempo de arregaçar a batina cantando quem me vê assim dançando não pense que fiquei louco não sou padre não sou nada virei secular há pouco, tempo de atravessar a cidade quase com o sol a entrar na igreja para as matinas (AMS, p.78-80).

Há um excerto próprio dos espetáculos populares em A porteira do mundo (1967), quando o narrador de primeira pessoa [romance de memória] ironiza a preparação de seu próprio casamento. O autor reutiliza este mesmo excerto no conto Da Peixa (GEP, p.46-57), texto de tom inusitado, sendo que cada item vai ser utilizado como subtítulo dos parágrafos. Na parte final do texto, o discurso é retomado e é apresentado em sua totalidade com a inversão dos versos, apresentando uma variação explícita: 


\begin{tabular}{|c|c|}
\hline $\begin{array}{l}\text { [...] o cortejo, surgindo e desapa- } \\
\text { recendo, os vinte homens dan- } \\
\text { çadores, os dezenove papagaios, } \\
\text { os dezoito queijos de coalho, os } \\
\text { dezessete caçadores, os dezesseis } \\
\text { trabalhadores, os quinze tenen- } \\
\text { tes-lanceiros, os catorze carapi- } \\
\text { neiros, as treze varas de ferrão, } \\
\text { os doze bois de carretão, os onze } \\
\text { cavalos baixeiros, os dez doutores } \\
\text { engenheiros, os nove negros de } \\
\text { chicote, os oito marcando xote, } \\
\text { as sete salas de quadrilha, as seis } \\
\text { salas de guerrilhas, as cinco me- } \\
\text { sas de jantar, os quatro padres no } \\
\text { altar, as três parelhas de padri- } \\
\text { nho, as duas canadas de vinho, e a } \\
\text { moça pra casar (GEP, p.57). }\end{array}$ & $\begin{array}{l}\text { Uma moça pra casar, duas ca- } \\
\text { nadas de vinho, três parelhas } \\
\text { de padrinho, quatro padres no } \\
\text { altar, cinco mesas de jantar, } \\
\text { seis valentões de guerrilha, } \\
\text { sete salas de quadrilha, oito } \\
\text { dançando xote, nove negras } \\
\text { no chicote, dez doutores de } \\
\text { engenharia, onze cavalos bai- } \\
\text { xeiros, doze bois de carretão, } \\
\text { treze varas de ferrão, catorze } \\
\text { carapineiros, quinze tenentes } \\
\text { lanceiros, dezesseis trabalha- } \\
\text { dores, dezessete caçadores, } \\
\text { dezoito queijos de coalho, } \\
\text { dezenove papagaios, vinte } \\
\text { homens dançadores (BORBA } \\
\text { FILHO, 1967, p.155). }\end{array}$ \\
\hline
\end{tabular}

Destaco, ainda, em Os ambulantes de Deus (1976), a estrofe:

\author{
Senhor padre capelão, \\ dance bem nesta função \\ vá tirar suas esmolas \\ pra você e o sacristão (BORBA FILHO, 1976, p.112).
}

Retomada pelo autor, na teatralização de 0 padre cuja transformação se dá através da prosificação, espécie de farsa ridicularizadora de pessoas sérias, para estabelecer o impacto: “[...] e as cinco beatas entravam na sala cantando e batendo palmas cadenciadas senhor padre ermitão dance bem nessa função vá tirar suas esmolas pra você e o sacristão [...]" (BORBA FILHO, 1966, p.78).

Borba Filho usa de muitos subterfúgios para desenvolver a sua escritura. O seu narrador em Deus no pasto (1972, p.68-73) discorre sobre duas velhinhas gêmeas, "iguaizinhas”, chamadas Manu e Giuda. 
Elas estão à procura de uma cama que haviam enviado para o conserto e o "consertador" desaparecera com ela. Desesperadas, pedem ajuda. Enquanto elas falam, são observadas pelo narrador: "e minha imaginação deformada já procurava criar uma história que com toda a certeza não seria melhor do que a experiência por que as duas estavam passando [...]". A história ressurge de fato em "Sete dias a cavalo", com o título "Retratos e flores", texto já estudado no segundo capítulo deste livro. As gêmeas têm outros nomes, o tema é outro, mas a cama em que elas dormem tem também um grande destaque, e o conto funciona como um traço autotextual inconfundível. Já o conto "A enchente" (AMS, p.41-42), inserido em "10 histórias da Zonada-Mata", corresponde na íntegra a um texto localizado na quarta parte de Os ambulantes de Deus (1976), como pode ser ilustrado com o primeiro e último período dos dois textos. O texto primeiro, neste exemplo de autotexto, pertence à trilogia, pois Os ambulantes de Deus têm uma escritura posterior:

Marulhou, gorgolejou, ela sentiu mais que ouviu a corrente, gorgolejou, estava nos pés, ela na beira da cama, e o defunto?, [...]. No alto do frontal, na escuridão e sob a chuva, o carneiro de pedra branca, sentado montava guarda (AMS, p.41-42).
Marulhou, gorgolejou, ela sentiu mais que ouviu a corrente, gorgolou, estava nos pés, ela na beira da cama, e o defunto?, [...]. No alto do frontal, na escuridão e sob a chuva, o carneiro de pedra branca, sentado, montava guarda (BORBA FILHO, 1976, p.99-100).

Não importa que teoria se aplique, o texto hermiliano está apto a atuar como suporte, para aplicação de variadas teorias na análise do material literário, representativo da atualização de discursos anteriores. Neste fluxo intenso de autotextualidade, infiro que a escritura hermiliana desenvolve um projeto literário que acoberta um macrotexto e mesmo que se diga ser Borba Filho um mestre da retomada de 
discursos anteriores, ele não deixará de ser um escritor que trabalha a linguagem com objetivos relacionados a referentes do mundo objetivo, quase sempre em forma de contestação, e o que não está implícito fica subentendido, quando o leitor, através dos silêncios do texto, perscruta a significação latente. A utilização de discursos preexistentes mobiliza técnicas a serviço de uma crítica reiterativa que enfatiza o envolvimento do autor com a sua percepção de mundo, ressaltando o comportamento de uma literatura para "mostrar o funcionamento da Máquina do Mundo, que o destino movimenta, e por cujas engrenagens, traiçoeiras e perigosas, a desvalida, a imprevidente criatura humana que sempre é colhida", pois afinal, o que se depreende da literatura deste escritor "é o seu diálogo com essa mesma vida" que se apresenta cheia de incidentes, na vistosa exterioridade que compõe os fatos (BRITO, 1976, p.16).

Introduzindo um outro veio da escritura hermiliana, faço-o para chamar a atenção para o adagiário popular, quer venha este em forma de provérbio, máxima, dito popular, frases feitas, expressões, entre outras modalidades da paremiologia, como está também em A pedra do reino, de Ariano Suassuna, literatura de cordel, literatura latino-americana, Bíblia Sagrada e tantas outras modalidades da literatura. Em Borba Filho, pois, é possível, também, detectar a representação do popular, através dos provérbios e congêneres, o que mostrarei no tópico seguinte, quando discuto aspectos conceituais do provérbio, por reconhecer a sua ênfase na Literatura.

\section{O palimpsesto paremiológico}

o Novo Dicionário Aurélio ensina que o provérbio é “[...] máxima ou sentença de caráter prático e popular, comum a todo um grupo social, expressa em forma sucinta e geralmente rica em imagens". Há toda uma gama sinonímica que levaria ao adágio, aforismo, pensamento, apotegma, rifão e anexim. Outros sinônimos surgiriam, numa 
busca mais acurada, podendo-se acrescentar ditos, ditados populares, frases feitas, clichês e outros.

André Jolles (1976) não distingue entre ditado ou provérbio, aspectos aos quais chama de forma breve. No entanto, este estudioso distingue o provérbio da locução. Entre outros traços de diferenciação, Jolles destaca que as locuções são provindas de indivíduos identificáveis, embora se atualizem posteriormente fora do seu contexto de origem. Exemplifica com "tempestade num copo de água", cuja paternidade é atribuída a Montesquieu.

Já para Hernâni Donato, (apud Magalhães Junior, 1974), citar provérbios é proclamar vivência. Classifica os provérbios em acusatórios, consoladores, didáticos, esperançosos, defensivos, restritivos, avisadores, edificantes, estimulantes, tranquilizantes e outros. Os provérbios existem para todas as horas e situações e qualquer que seja a sua classificação refletem "situações e anseios universais e eternos". Sendo fruto coletivo, recolhem não a experiência individual, mas a de muitos, funcionando como o espírito e o esforço da sabedoria popular.

Mas apesar da sua praticidade, o provérbio nem sempre surge do nada, podendo ter sua origem no espaço erudito, o que corresponderia, talvez, a locuções reformuladas. Assumido pelo povo, então o provérbio se torna popular. 0 povo é que sabe as coisas, diz a sabedoria popular. A essência do provérbio está contida no imaginário coletivo que se prolifera também como fazendo parte de uma memória atávica, perdendo-se a sua origem no tempo. Isto leva Barthes (1989, p.74) a dizer: "o provérbio popular prevê, muito mais do que afirma, permanece a fala de uma humanidade que se está constituindo, e não de uma humanidade já constituída". Esta afirmação barthesiana, quando aplicada aos provérbios, utilizados ou recriados por Borba Filho, permite aferir uma nova perspectiva, pois, neste escritor, a humanidade, ou melhor, a sociedade já está constituída, mas precisa ser transformada numa sociedade que deveria ser, se é possível aqui introduzir uma visão utópica do mundo real, uma visão em que a contestação tem o mesmo peso da utopia, o que favorece a distopia, pela 
não realização de "visões de mundo" que, apontadas para um mundo melhor, não vigem, enquanto processo de transformação. Borba Filho, encarando a paremiologia com uma função determinada, utiliza os provérbios, de modo prático, usando-os no desenvolvimento do seu objetivo literário, sempre contactando com o mundo objetivo, anteparo para um universo estético, em que o provérbio sedia os aspectos da artisticidade.

"Para os grandes males, grandes remédios", sai do seu plano usual de significação, assumindo outros significados como está em "As lagartixas indianas" (GEP, p.32): "Corria para a farmácia de plantão, [...] voltava com duzentos e cinquenta gramas de sal-amargo, purgante pra boi, quantidade inusitada para os grandes males, grandes remédios [...]".

Greimas (1975, p.288) elucida o enfoque acima, pois associando os provérbios aos ditados, delega-os como "elementos significantes de um código particular". Para ele, em relação aos provérbios, "a descrição esquemática e estrutural do plano do significante dará conta das configurações do seu significado", o que me permite ver o provérbio como gerador de signos, semioticamente trabalhados, na adequação da significância paremiológica.

A significação do provérbio vai sempre depender do contexto. No conto "O almirante" (GEP), "um dia macaco é gente" ressalta a possibilidade de ascensão social, mas o que chama a atenção é o tom humorista que ridiculariza uma situação inusitada, própria do mundo real. Em "cada um nasce com a sua sina" é equivalente a "cada um é pro que nasce" (MOTA, 1982), encaixa-se no texto "As lagartixas indianas" (GEP) e revela a ironia, podendo-se dizer que o narrador seleciona personagens, representantes do poder instituído, com o fim de ridicularizá-las. É o poder trabalhando na ótica de Foucault (1999), através do método genealógico que evidencia a existência de formas de exercício de poder, associado ao aparelho do Estado. 0 poder em sendo repressivo "é o que reprime a natureza, os indivíduos, os instintos, uma classe [...]. Não será, então, que a análise do poder 
deveria ser essencialmente uma análise dos mecanismos de repressão?" (FOUCAULT, 1999, p.175).

Ainda neste conto "As lagartixas indianas", o narrador utiliza "uma mão lava a outra" para criticar atitude corriqueira do mundo real e ainda hoje tão presente nas situações políticas em que alguém quer tirar vantagens de determinadas situações, começando na carta de Pero Vaz de Caminha, em que este bajula o rei Dom Manuel e desperta a sua cobiça para depois pedir-lhe favores. Mas voltando ao provérbio supracitado, ele se encontra em Sêneca: manus manum lavat, (apud Ronai 1985). Em francês, italiano e inglês, assim como na tradução portuguesa, segundo Mota (1982), apresenta-se como "uma mão lava a outra e ambas o rosto", significando que "sem ajuda mútua muitas coisas não poderão ser realizadas", comentado por Magalhães Junior (1974), o que semioticamente significa união de forças para enfrentar o poder.

A respeito da aquisição de umas lagartixas indianas, o narrador desmonta a semântica do texto, introduzindo "cada um por si e Deus por todas", o que vai de encontro ao entusiasmo do dono das lagartixas. Este mesmo axioma está antecedido de "cada uma que trate de viver a sua vida". A sequência se encerra com "em tempo de murici cada qual cuide de si". 0 primeiro tem como matriz "cada qual trate de si e deixe os outros", significação explícita do egoísmo. Aproximando, "cada um por si e Deus por todos / cada um que trate de viver a sua vida", se estabelece uma redundância, o que enfatiza a crítica à alienação (lagartixas indianas tornam-se mais importantes que as pessoas). Neste contexto, no entanto, o ponto de relevância significativa está em "em tempo de murici cada qual cuide de si", provérbio explicado por João Ribeiro. Para ele, o termo "murici" é corruptela de "moreci" ou "murixy", nome indiano do cólera-morbo. 0 provérbio teria sido trazido ao Brasil no tempo da Colônia, aqui se confundindo com a voz indígena "murici". "A epidemia do murixi, sempre acompanhada de grande medo [o que justifica o seu emprego] explica a expressão 
melhor que a frutinha inócua do murici, que não se relaciona com nenhuma calamidade" (RIBEIRO, [1969?], p.217).

Com base na temática dos contos hermilianos, concluo que um provérbio desta natureza é representativo de uma realidade em que predominam o medo e a impotência diante das circunstâncias vivenciadas pelo povo, medo aqui, podendo ser visto, na esteira de Novaes (2007), que diz ser o medo parte da vida social e política e acrescenta: "o medo é o resultado da sensação permanente da fragilidade do homem (medo da morte) diante de um perigo difuso" (NOVAES, 2007, p.13).

Em "pior o remédio que a doença", no conto "Dom" (GEP, p.5873), variante de "pior a cura que o mal", este utilizado como sátira ao exercício da Medicina, como no verso 46, do canto XXII da Eneida, ou como está em Montaigne, livro III, cap. XIII, informação prestada para o Magalhães Júnior (1974). No conto hermiliano, conota uma dificuldade a ser vencida, que piora a situação. Relaciona-se com o paradigma "pior a emenda que o soneto", de onde infiro que, na realidade vivida e representada, nada pode ser mudado, uma vez que o explícito representa uma sociedade de risco de que fala Beck que, observando admissão de problemas, afirma: "Cada vez mais daquilo que é sistematicamente produzido em termos de sofrimento e opressão se torna visível, tendo de ser reconhecido por aqueles que o negavam" (BECK, 2010, p.62).

A respeito de uma personagem de nome Reduzido, numa situação absurda e fantástica, o narrador introduz "pequeno no tamanho e mais pequeno ainda nas ações". "Reduzido" associa-se a seres reais e o próprio hipocorístico conota insignificância, ironia velada à realidade representada, havendo uma alusão explícita à fala de Horácio, Epístolas, I, 7: “Ao pequeno convém coisas pequenas”, citado por Rónai (1985), o que justifica lembrar a relação transtextual.

Em "Cinco traques de velha" (GEP, p.105-116), o provérbio "Boa romaria faz quem em sua casa está em paz", que sequencia "e a cadeia cheia”, há uma forma de contestação ao mundo real e apresenta-se 
como variante de "boa romaria faz quem em sua casa fica em paz". No provérbio, o verbo "estar", indicando transitoriedade, aponta para uma realidade que pode ser modificada. Digo, inclusive, que este fato se insere na liquidez trabalhada por Bauman em várias obras e me detenho em Medo líquido (2008) para destacar o medo com que as pessoas conviviam, donde "Os perigos que tememos transcendem nossa capacidade de agir [...] [e] o sentimento de impotência - o impacto mais assustador de medo - reside, contudo nas ameaças percebidas ou imaginadas em si [...]" (BAUMAN, 2008, p.32). Este provérbio, segundo Mota (1982), corresponde ao espanhol no "hay mejor andar que en su casa estar" e ao inglês "there is no place like home", só para justificar a relação transtextual.

Foram compilados provérbios de O general está pintando, de modo especial, os mais significativos. Mas como não passa despercebido, o mesmo arranjo da paremiologia em Sete dias a cavalo, segundo volume da trilogia de contos, utilizado para averiguação.

O tom satírico é uma marca característica do estilo hermiliano e o narrador utiliza algumas personagens como vetoras que expandem o seu estilo. O cabo Luís, no conto Hierarquia (SDC, 1974), tem atitudes específicas e o narrador aplica a ele o provérbio, dizendo que ele andava "devagar como quem procura com os pés penico no escuro". $\mathrm{O}$ adágio, que caracteriza o discurso do meio popular, vai além do sentido do texto, pois além do tom pejorativo busca ridicularizar a personagem representativa da repressão policial, como um recurso para dirimir a violência instalada, embora se saiba que, na ótica de Foucault (2011, p.207), “a questão da verdadeira vida não parou de se extenuar, de se atenuar, de se eliminar [...]”, sem ir além disso na realidade representada. Em relação ao provérbio, é pertinente supor que o sentido remete à morosidade da política, na prestação de serviço à comunidade. Neste conto, ainda em relação ao mesmo tema, com predominância do mesmo tom, destaca-se "caminhar em volta como um peru", cujo sentido também se associa à lerdeza, descompromisso. É relevante chamar a atenção para a ampliação do provérbio “em 
tempo de murici cada qual cuide de si”, já estudado. É um caso típico de intertextualidade, mas o narrador desconstrói o discurso e, agora, a crítica a uma realidade marcada pelo medo e a impotência do mundo empírico já não se apresenta veladamente, patenteando-se de modo explícito. 0 provérbio estrutura-se assim: "se em tempo de murici cada qual cuide de si em tempo de militar é bom ficar sob a proteção das armas". Discurso desconstruído, polarizando o significado, uma vez que o narrador diz uma coisa, querendo dizer outra, o que pode ser captado nos interstícios discursivos.

Referindo-se ao sadismo de um promotor que se excitava para copular, lendo a seção fúnebre do jornal com noticiários que revelavam "segredos da humanidade despojada na morte e na moradia", o narrador apresenta um provérbio utilizando como paradigma outras matrizes: "cada um se excita da maneira que melhor lhe convém", como "cada um dá o que tem", "cada um é o pro que nasce", "cada um faz o que pode", "cada um se diverte como gosta", "cada um tem o seu jeito de matar pulgas" (MOTA, 1982).

No conto "Os tropeiros do céu", num tema que introduz a crítica aos baixos salários, o narrador, através da antítese, apresenta categorias de tempo e espaço. Destaca a importância do problema e o nível de contestação. No discurso das personagens, após "está se acabando o tempo da exploração", (o que pode ser lido como uma ironia, no contexto), o adágio "entra inverno e sai inverno, entra verão, sai verão", estabelece a indefinição dos problemas do mundo real, tal como explicita Jameson:

Aparece então algo como um conceito de mudança sem o seu oposto: e afirmar isso significa testemunhar sem apelação as nossas duas primeiras antinomias se dobrarem uma sobre a outra, uma vez que, do ponto de vista da mudança, torna-se impossível distinguir espaço de tempo ou objeto de sujeito (JAMESON, 1997, p.24). 
Em "O traidor", que desenvolve um tema de contestação, o autor/ narrador, reutilizando paradigmas existentes na paremiologia, constrói o discurso com vistas à representação do real "em tempo de ditadura ninguém conspira, cochicha, trama”. No mesmo texto, discorrendo sobre uma personagem afeita a ditos e gracejos sobre as mulheres, retoma o nível de linguagem proibida e, usando um eufemismo para o órgão sexual masculino, apresenta um provérbio poético, [trabalhado em torno de paralelismos, antíteses, ritmos e rimas, segundo Feitosa (1984)], de onde sobressai o teor pornográfico: "mulher que se espreguiça ou tem sono ou quer pica".

Investindo no aproveitamento de um processo rítmico e rímico, para significar indiferença ante o sofrimento e angústia, surge, de forma irônica, "nem te ligo, nem te desligo e laritas", retirado provavelmente da oralidade. O último termo, "laritas", um neologismo que sintetiza o que foi dito anteriormente, pode conotar "nada". Já o efeito hiperbólico de "chorar lágrimas grossas como punhos", equivalente à matriz "chorar lágrimas de sangue", clichê que se situa no espaço discursivo como imagem de intenso desespero. No texto hermiliano, o narrador, fugindo do lugar comum, situa o discurso recriado num espaço em que se contesta uma situação de opressão desmedida. Borba Filho viveu em tempos sombrios, de que fala Arendt (2008). "Os tempos sombrios [...] não constituem uma raridade na história, embora talvez fossem desconhecidos na história americana, que por outro lado tem a sua bela parcela, passada e presente, de crimes e catástrofes" (p.9). Aqui no Brasil e, por extensão no Nordeste, muitos escritores, através de sua arte, representam estes tempos sombrios, não só através dos aspectos socioculturais e históricos, mas também através dos planos estético-literários e estilísticos, estabelecendo através de uma linguagem ambígua e ambivalente, semioses diversificadas.

Para resolver um fato inusitado, o narrador introduz na área contextual "o touro devia ser pegado pelos chifres", significando “enfrentar e decidir a situação", segundo Mota (1982). É como se o narrador se relacionasse com uma realidade em que seria necessário 
coragem para inverter a situação existente. Enfatizando o narcisismo de uma personagem, o narrador dá um tom de volúpia ao contexto, fazendo ressurgir "quem quer o meu me dá o seu", podendo ser feita uma leitura em que o egoísmo, na prática do prazer, comandando as ações humanas, alija do contexto social, senso de responsabilidade, donde brota a alienação e a indiferença, frente às soluções cabíveis à mudança.

No conto "O perfumista", o narrador, retomando o discurso de trechos do mamulengo, introduz no discurso o provérbio "quem vai ao vento perde o assento", que tem a variante "quem vai ao ar, perde o lugar". O mesmo provérbio circula em francês com a forma "qui quitte sa place la perd" (quem deixa seu lugar, perde-o -MAGALHÃES JUNIOR, 1974). Supõe-se, no contexto, o indício de não comprometimento, como acontece no mundo real.

Em "O palhaço", texto em que a personagem é feia e insignificante, o narrador introduz "eu vou ali e volto já e cabeça de bagre não tem o que chupar”. É interessante observar que a significação deste provérbio está na segunda parte. O termo "bagre", como gíria, significa pessoa feia e a lexia "cabeça de bagre" tem como resultado pessoa destituída de bom senso (MOTA, 1982), o que marca este texto como isotopia do real.

Num conto do qual se pode depreender uma crítica ao latifúndio, o provérbio "cada um por si e Deus por todos" representa a síntese do texto, se este for associado ao mundo empírico, o provérbio tem variantes como "cada um trate de si e deixe os outros", "cada um sabe de si e Deus por todos" (MOTA, 1989). Há ainda uma variante, do século XVI, "cada um para si e Deus para todos" (CASANOVAS, 1973).

E assim apresentei, em Sete dias a cavalo, um conjunto de provérbios. No terceiro volume, As meninas do sobrado, o narrador investe mais em frases feitas, ditos populares, expressões estereotipadas, clichês. Selecionei nesta obra apenas dois provérbios para análise, o que se justifica pela sua representatividade. 
Num conto em que é contestada uma prática política degradada, o provérbio "quem semeia ventos colhe tempestades" é a isotopia da temática, associada à noção de perigo. Fica subentendida a intenção do narrador de ressaltar aspectos ligados ao mundo objetivo, consequência de tempos marcados por opressão política, em que a representação do mundo real aponta para as arbitrariedades do poder, temática discutida amplamente por Foucault em várias obras e aqui eu faço o arremate dizendo com Foucault (2010, p.361): “É bom, por razões éticas ou políticas, que o poder que exerce o direito de punir inquiete-se, sempre com este estranho poderio e não se sinta jamais tão seguro de si próprio", o que talvez possa diminuir o medo que grassa na sociedade representada.

O provérbio supracitado corresponde à variante do provérbio português "quem semeia abrolhos espinhos colhe" com outra variante "quem semeia urzes colhe espinhos" (MAGALHÃES JUNIOR, 1974).

Em A testemunha, conto em que o tempo é representativo dos desmandos dos poderosos na prática da "justiça", o narrador retoma o discurso de Kempis, em A imitação de Jesus Cristo: "o homem põe e Deus dispõe" (homo proponit, sed disponit) (MOTA, 1982), muito encontrado em contextos orais. No discurso hermiliano, o provérbio é remanejado de tal modo que a sua significação fica distorcida, na sua nova estruturação: “a lei põe o homem não dispõe". O nível de ambiguidade se intensifica pelo arranjo sintático, determinado pela ausência de vírgula, separando os dois sintagmas e pela elipse do nexo de ligação. O verbo "dispor" empregado intransitivamente é responsável pelo silêncio cujo significado supera qualquer discurso, podendo-se auferir que o não-dito tem maior força expressiva que o discurso escrito. Daí dizer-se que a leitura do mundo real manipula a significação do silêncio.

Encerrando-se este tópico, convém lembrar que trabalhar a paremiologia e modalidades afins do provérbio é contatar com escritores que investem na pesquisa para, através da captação da visão de mundo popular, munir a sua escritura de elementos que são a representação 
da identidade de personagens, fatos, ações e vivências de um modo de ser, como guardião de memórias e vivências culturais como Guimarães Rosa, Ariano Suassuna, Leandro Gomes de Barros, Patativa do Assaré e tantos outros que gerem o texto literário com a exata medida do vir -a-ser da literatura em espaços significativos de buscas que, às vezes, mesmo contraditórias, desenvolvem uma função específica. 